\title{
Determining the Influence of Spray Quality, Nozzle Type, Spray Volume, and Air-Assisted Application Strategies on Deposition of Pesticides In SOYBEAn CANOPY
}

\author{
R. C. Derksen, H. Zhu, H. E. Ozkan, R. B. Hammond, A. E. Dorrance, A. L. Spongberg
}

\begin{abstract}
Field studies were established in north central Ohio to determine the effect of different application strategies on targeting of foliar pesticides in narrow-row $(18 \mathrm{~cm})$ soybeans. Several different application factors were tested, including spray quality, nozzle type, air-assistance, and spray volume. In 2005, the spray mix included a fungicide. In 2006, in addition to the fungicide, an insecticide was included. Plant samples were removed from each test plot, and stems and leaves from the bottom third and middle third of the plant were separated for analysis. Overall, there was significantly less active ingredient found in the lower third of the canopies than the middle third, and significantly less pesticide residue was found on stems than leaves from the same canopy location. Significantly more fungicide residue was found on lower leaves treated by the medium-quality XR8004 flat-fan nozzle in 2005 than the coarse-quality XR8005 flat-fan nozzle. There were no differences in fungicide residue found on middle canopy leaves between the fine, medium, and coarse quality flat-fan nozzles. The twin-fan pattern nozzles (Turbo Duo and TwinJet) produced the lowest amounts of fungicide residue on the lower leaves in 2005. The mechanical canopy opener produced significantly higher fungicide residues on middle canopy leaves than all other treatments. The Jacto air-assist sprayer using JA3 hollow-cone nozzles produced the highest fungicide residues on lower canopy leaves in 2005. There were some statistical differences between the amounts of fungicide and insecticide residue found on plant tissue in 2006 because of the high amount of variability in the sample data. Overall in 2006, the higher volume XR8004 treatment $\left(187 \mathrm{~L} \mathrm{ha}^{-1}\right)$ and the twin-fan TTJ60-11003 treatment at $145 \mathrm{~L} \mathrm{ha}^{-1}$ performed similar to the Jacto sprayer making applications at $145 \mathrm{~L} \mathrm{ha}^{-1}$ using either flat-fan or hollow-cone nozzles. In general, higher volume applications produced higher amounts of fungicide and insecticide residue on leaves from the middle of the canopy for conventional flat-fan and air-assist applications. Spray volume had less affect on residues measured on leaves from the lower canopy area. Across two years of different canopies at the same spray volume $\left(145 \mathrm{~L} \mathrm{ha}^{-1}\right)$, the Jacto sprayer using JA3 hollow-cone nozzles produced more fungicide residue on middle canopy stems and lower canopy leaves than the medium-quality XR8004 flat-fan nozzle.
\end{abstract}

Keywords. Air-assist, Coverage, Deposit, Disease, Insect, Soybean, Spray.

$\mathbf{P}$

esticides are the only control option for many potentially damaging food crop insect pests and diseases. It is important to deliver those materials where they will have the greatest biological impact and yield

Submitted for review in December 2007 as manuscript number PM 7320; approved for publication by the Power \& Machinery Division of ASABE in August 2008.

Names are necessary to report factually on available data; however, the USDA neither guarantees nor warrants the standard of the product, and the use of the name by USDA implies no approval of the product to the exclusion of others that may also be suitable.

The authors are Richard C. Derksen, ASABE Member Engineer, Agricultural Engineer, and Heping Zhu, ASABE Member Engineer, Agricultural Engineer, USDA-ARS Application Technology Research Unit, Wooster, Ohio; H. Erdal Ozkan, ASABE Member Engineer, Professor, Department of Food, Biological, and Agricultural Engineering, The Ohio State University, Columbus, Ohio; Ronald B. Hammond, Professor and Entomologist, Department of Entomology, The Ohio State University, Wooster, Ohio; Anne E. Dorrance, Professor and Plant Pathologist, Department of Plant Pathology, The Ohio State University, Wooster, Ohio; and Alison L. Spongberg, Associate Professor, Department of Environmental Sciences, University of Toledo, Toledo, Ohio. Corresponding author: Richard C. Derksen, USDA-ARS, Agricultural Engineering Building, 1680 Madison Ave., Wooster, OH 44691; phone: 330-263-3869; fax: 330-263-3953; e-mail: rich.derksen@ars.usda.gov. benefit. Food crops may require targeting of fruit as well as foliage. Sometimes tree trunks require treatment rather than foliage. Protection against wheat scab requires treatment of the wheat head, while management of different forms of wheat rust requires treating the stem and leaves below the head. In soybeans, white mold predominately infects soybean flowers and stems, while Asian soybean rust infection usually starts at lower plant surfaces and moves upwards during R3 and R5 reproductive stages. Thrips may be found predominately on the upper portions of an ornamental canopy, while whiteflies and aphids prefer the undersides of leaves. Improved targeting of sprays would not only help manage pest problems but could also reduce waste and overall pesticide use.

Air-assist sprayers can effectively deliver pest control agents inside dense canopies (Reichard et al., 1979; Fox et al., 1982). Several studies have demonstrated that, at the same carrier rate, air-assisted delivery improves canopy penetration in row crops compared to conventional delivery through non-air-assisted techniques (Derksen et al., 2001; Mueller et al., 2002; Piché et al., 2000; Womac et al., 1992). Through analysis of fluorescent tracer deposits on leaves, Derksen et al. (2007) found that air-assisted delivery produced higher underleaf spray coverage on bell pepper plants 
than non-air-assisted delivery using either twin-fan and airinduction nozzles. None of these previous studies were conducted in canopies as potentially dense as narrow-row soybeans at the R3-R5 reproductive stage.

Foliar coverage and deposition produced by twin-fan or dual-fan nozzles and low-drift, air-induction nozzles has not been widely reported for dense canopy production systems. Zhu et al. (2002) demonstrated that inclining a single fan spray pattern discharge $15^{\circ}$ forward did not improve spray penetration in a peanut canopy. Derksen et al. (2007) reported that foliar spray deposits were similar for a $60^{\circ}$ twin-fan nozzle and a low-drift, air-induction nozzle; however, larger droplet size sprays such as that produced by the air-induction nozzle produced lower foliar spray coverage than the twinfan nozzle. Zhu et al. (2004) found that air-induction nozzles produced the highest deposits on targets placed on the ground at the bottom of a single-row peanut canopy compared to hollow-cone, twin-fan, and conventional flat-fan nozzles, and the twin-fan nozzle produced higher deposits than a hollow-cone nozzle.

Because the risk of Asian soybean rust (ASR) (Phakopsora pachyrhizi) infection to South and North American crops is relatively new, there have been few published reports evaluating application strategies. In snap bean rust management (Uromyces phaseoli typcica), Mullins et al. (1981) reported that high application rates $\left(574 \mathrm{~L} \mathrm{ha}^{-1}\right)$ and three nozzles per row were more effective than a single over-row nozzle in covering lower leaf surfaces of snap beans; however, fungicide applications at $187 \mathrm{~L} \mathrm{ha}^{-1}$ with a single over-row nozzle were as efficacious as any other treatment. Cunha et al. (2006) studied the effect of different spray volumes $(115$ and $160 \mathrm{~L}$ $\mathrm{ha}^{-1}$ ) and nozzle types on ASR management in soybeans planted in $50 \mathrm{~cm}$ row spacing. Compared to pre-orifice and air-induction nozzles, a standard flat-fan nozzle making applications at $160 \mathrm{~L} \mathrm{ha}^{-1}$ produced the most uniform spray distribution in the canopy. However, Cunha et al. (2006) reported no differences by spray volume or nozzle type in managing rust or in crop yield. Other soybean trials have only reported the effect of application parameters on spray coverage measured on artificial targets. Ruden et al. (2006) and Wolf and Daggupati (2006) demonstrated that spray quality and spray volume affected spray coverage on water-sensitive paper placed in soybean canopies. None of these previous reports evaluated the fate of sprays, particularly active ingredients, across soybean plant canopies.

The objective of this research was to determine the influence of spray quality, mechanized canopy movement, airassisted delivery, and nozzle spray patterns on soybean canopy penetration and deposition, which could aid in selection of efficacious means for delivering pesticides to different parts of the soybean canopy for effective management of diseases and insects that may predominantly reside in hard-toreach parts of the canopy. Evaluation of pesticide residue on stem and leaf tissue was used to characterize treatment effectiveness to provide a true representation of where spray was deposited on different portions of a plant canopy rather than on artificial targets.

\section{Materials ANd Methods}

Field trials were conducted on The Ohio State University's research farms around Wooster, Ohio, in 2005 and 2006.
Table 1. Crop conditions for soybean canopy spray penetration trials.

\begin{tabular}{ccc}
\hline Crop Parameter & 2005 & 2006 \\
\hline Variety & Seed Consultants & Pioneer \\
& SC9284 & $92 \mathrm{~B} 38$ \\
Seeding rate (seeds/acre) & 210,000 & 200,000 \\
Planting date & 5 May & 18 April \\
Average plant height $(\mathrm{cm})$ & 112 & 106 \\
Leaf area index & 6.40 & 3.44 \\
\hline
\end{tabular}

Field plots were arranged in a randomized complete block (RCB) design, with treatments randomly assigned to plots within each of four blocks or replicates. Each plot was approximately $46 \mathrm{~m}$ long and $4.6 \mathrm{~m}$ wide. A $3.3 \mathrm{~m}$ drive row was cut out of the field between each block. Soybeans were planted in drilled rows with $18 \mathrm{~cm}$ row spacing. Table 1 shows the seed variety, planting date, and planting rate for each field.

Pesticide applications were made when the soybeans reached the R4-R5 reproductive growth stage. Plant height and leaf area index (LAI) were measured to determine canopy conditions at the time of applications. Plant height was measured on plant samples removed from the fields. LAI of the soybean canopy was determined using an LAI-2000 plant canopy analyzer (LI-COR, Inc., Lincoln, Neb.) with two sensor modes. Three small sections in each plot were randomly selected for the LAI measurement. For each small section, four measurements of LAI at four orientations in a square shape were conducted. The sky was fully covered by clouds at the moment of measurement. The LAI sensor was also calibrated under fully cloudy conditions. Overall, the canopy was denser and taller in 2005 than 2006.

Meteorological conditions were monitored during all applications. A portable tripod weather station equipped for measuring wind speed and direction (model 03001 Wind Sentry Set, R.M. Young, Inc., Traverse City, Mich.) was aligned northward $\left(0^{\circ}\right)$ and installed with the windset at a height of $2.3 \mathrm{~m}$. An air temperature and relative humidity probe (model HMP-45C, Campbell Scientific, Logan, Utah) was mounted at a height of $1.8 \mathrm{~m}$. Data were recorded every second with a datalogger (model CR23X, Campbell Scientific, Logan, Utah). Table 2 shows the range of meteorological conditions experienced on the testing days for each year. Wind conditions were light and variable in 2005, with a mean speed of $1.3 \mathrm{~m} \mathrm{~s}^{-1}$. Winds were less variable in 2006 , with a mean speed of $2.5 \mathrm{~m} \mathrm{~s}^{-1}$ during test runs. Air temperature and humidity were typical for midsummer.

Table 3 shows the eight spray treatments evaluated in 2005, including an air-assisted sprayer and a conventional boom sprayer with seven different nozzles and a selfdesigned canopy opener. Travel speeds, nozzle output, and spray quality designations based on ASABE Standard S572 (ASABE Standards, 2004) are also shown in table 3. Application rate for all treatments was adjusted by either travel speed or flow rate to $145 \mathrm{~L} \mathrm{ha}^{-1}$. The air-assisted sprayer (Advance

Table 2. Meteorological conditions during application in soybean field trials in 2005 and 2006.

\begin{tabular}{|c|c|c|c|c|}
\hline $\begin{array}{l}\text { Application } \\
\text { Date }\end{array}$ & $\begin{array}{l}\text { Wind } \\
\text { Speed } \\
\text { Range } \\
\left(\mathrm{m} \mathrm{s}^{-1}\right)\end{array}$ & $\begin{array}{c}\text { Wind } \\
\text { Direction } \\
\text { Range } \\
\left(^{\circ}\right)\end{array}$ & $\begin{array}{l}\text { Ambient } \\
\text { Temp. } \\
\text { Range } \\
\left({ }^{\circ} \mathrm{C}\right)\end{array}$ & $\begin{array}{c}\text { Ambient } \\
\text { Relative } \\
\text { Humidity } \\
(\%)\end{array}$ \\
\hline 2 Aug. 2005 & $0.0-3.5$ & $2-360$ & $29.2-32.2$ & $38-69$ \\
\hline 31 July 2006 & $1.1-4.3$ & $154-277$ & $29.9-32.4$ & $59-75$ \\
\hline
\end{tabular}


Table 3. Sprayers and operating parameters used in soybean field trials in 2005 at an application rate of $145 \mathrm{~L} \mathrm{ha}^{-1}$.

\begin{tabular}{|c|c|c|c|c|c|c|c|c|}
\hline \multicolumn{2}{|c|}{ Treatment } & \multirow[b]{2}{*}{$\begin{array}{c}\text { Pressure } \\
(\mathrm{kPa})\end{array}$} & \multirow{2}{*}{$\begin{array}{c}\text { Travel } \\
\text { Speed } \\
\left(\mathrm{km} \mathrm{h}^{-1}\right)\end{array}$} & \multirow[b]{2}{*}{$\begin{array}{c}\text { Flow } \\
\left(\mathrm{L} \mathrm{min}^{-1}\right)\end{array}$} & \multirow[b]{2}{*}{$\begin{array}{c}\text { Spray } \\
\text { Quality[a] }\end{array}$} & \multicolumn{3}{|c|}{ Droplet Spectrum } \\
\hline Sprayer & Nozzle & & & & & $\begin{array}{l}D_{V .10} \\
(\mu \mathrm{m})\end{array}$ & $\begin{array}{l}D_{V .50} \\
(\mu \mathrm{m})\end{array}$ & $\begin{array}{l}D_{V .90} \\
(\mu \mathrm{m})\end{array}$ \\
\hline Jacto air-assist sprayer & Jacto JA3 & 1062 & 11.3 & 1.32 & Fine & 82 & 118 & 182 \\
\hline Boom sprayer + canopy opener & XR8004 & 214 & 11.3 & 1.32 & Medium & 122 & 321 & 549 \\
\hline Boom sprayer & XR8004 & 214 & 11.3 & 1.32 & Medium & 122 & 321 & 549 \\
\hline Boom sprayer & XR8002 & 290 & 6.4 & 0.76 & Fine & 89 & 180 & 349 \\
\hline Boom sprayer & XR8005 & 138 & 11.3 & 1.32 & Coarse & 144 & 384 & 632 \\
\hline Boom sprayer & Turbo Duo QJ90-TT11002 & 214 & 11.3 & 1.32 & Medium & 182 & 376 & 698 \\
\hline Boom sprayer & TwinJet TJ60-8004 & 214 & 11.3 & 1.32 & Medium & 147 & 286 & 486 \\
\hline Boom sprayer & TX-18 & 372 & 11.3 & 1.32 & Medium & 129 & 171 & 302 \\
\hline
\end{tabular}

[a] As defined by ASABE Standard S572 (ASABE Standards, 2004).

3000 pull-type agricultural sprayer, Jacto, Pompeia, Brazil) had an $18.3 \mathrm{~m}$ long air sleeve along the entire length of the boom. The outlet of the air sleeve was positioned behind the nozzles, and the air jet was delivered at a $58^{\circ}$ angle toward the liquid spray pattern, which was directed vertically toward the canopies. As measured with a handheld air velocity probe (model 8386A VelociCalc Plus air velocity meter, TSI, Inc., Shoreview, Minn.), the average air speed at the outlet of the sleeve was $34.4 \mathrm{~m} \mathrm{~s}^{-1}$. At the point where the air jet meets the spray stream $33 \mathrm{~cm}$ below the outlet, the average measured air speed was $11.8 \mathrm{~m} \mathrm{~s}^{-1}$. Jacto JA3 hollow-cone nozzles were used on the air-assist sprayer in 2005.

A three-point hitch plot sprayer with a $3.3 \mathrm{~m}$ offset spray boom served as the conventional boom sprayer. All nozzles were positioned along the boom using $50 \mathrm{~cm}$ spacing starting $50 \mathrm{~cm}$ from the rear tractor tire. Nozzles tested in 2005 with the offset boom sprayer (table 3 ) included three conventional flat-fan nozzles (XR8002, XR8004, and XR8005) representing fine, medium, and coarse spray qualities; a conventional (one piece) twin pattern nozzle (TwinJet TJ60-8004) with $60^{\circ}$ of fan angle between two spray patterns; a Turbo Duo nozzle body containing two pre-orifice flat-fan tips (Turbo Flat Fan QJ90-2XTT11002); and a hollow-cone nozzle (TX-18). The Turbo Duo nozzle assembly produced two flat spray patterns, with one spray pattern at a $45^{\circ}$ angle forward of vertical and another spray pattern at a $45^{\circ}$ angle backward from the sprayer travel direction. All nozzles used on the conventional sprayer were manufactured by Spraying Systems Co. (Wheaton, Ill.).

A prototype mechanical canopy opener was designed and fabricated to bend and open the canopy ahead of the nozzle output. The canopy opener was used to evaluate alterative techniques for opening up a canopy and improving spray penetration. It was fitted to the conventional boom sprayer when needed. The canopy opener consisted of a length of electrical conduit pipe with a $3.2 \mathrm{~cm}$ outside diameter that extended the length of the spray boom. The conduit pipe was mounted $56 \mathrm{~cm}$ below and $25 \mathrm{~cm}$ ahead of the nozzles on the spray boom. The complete design of the canopy opener is described by Zhu (2006).

Treatments evaluated in 2006 are described in table 4. The Jacto JA3 and boom sprayer XR8004 treatments remained the same as in 2005. All nozzle treatments, however, were fitted on the Jacto sprayer in 2006, and the air system was only operated for those treatments requiring air-assisted delivery. Travel speed remained constant at $11.3 \mathrm{~km} \mathrm{~h}^{-1}$ for all treatments in 2006, but application rates varied, as shown in table 4. The TTJ60-11003 nozzle was included in the 2006 tests because the angle between the forward and rear fan patterns was narrower $\left(60^{\circ}\right)$ than with the Turbo Duo nozzle $\left(90^{\circ}\right)$ used in 2005 , and this was thought to have a better chance of penetrating the canopy. In 2006, the effect of spray volume on canopy penetration was evaluated by using both the XR8004 and Jacto 11002AXI treatments at two different pressures. The flat-fan 11002AXI nozzle and the hollowcone JA3 nozzle were included to evaluate the effect of spray pattern on the performance of the air-assist sprayer.

Droplet sizes from nozzles used in the tests were measured with the Oxford Lasers VisiSizer particle/droplet image analysis system (Oxfordshire, U.K.). Droplet size distributions were determined $30 \mathrm{~cm}$ below the nozzle orifice in a continuous scan across the centerline of the long axis of the spray pattern. A minimum of 10,000 droplets were counted at each sampling position for the droplet size distribution analysis. Droplet size measurements were made without the aid of any air-assisted delivery for the nozzles from the Jacto sprayer. Based on the water droplet break up equation (eq. 1) given by Lefebvre (1989):

$$
U_{R}=784 D^{-1 / 2}
$$

where $U_{R}$ is critical relative velocity $\left(\mathrm{m} \mathrm{s}^{-1}\right)$ and $D$ is droplet diameter $(\mu \mathrm{m})$ for the measured air speed conditions, the

Table 4. Sprayers and operating parameters used in soybean trials in 2006.

\begin{tabular}{|c|c|c|c|c|c|c|c|c|}
\hline \multicolumn{2}{|c|}{ Treatment } & \multirow[b]{2}{*}{$\begin{array}{c}\text { Pressure } \\
(\mathrm{kPa})\end{array}$} & \multirow[b]{2}{*}{$\begin{array}{c}\text { Flow } \\
\left(\mathrm{L} \mathrm{min}^{-1}\right)\end{array}$} & \multirow{2}{*}{$\begin{array}{c}\text { Application } \\
\text { Rate } \\
\left(\mathrm{L} \mathrm{ha}^{-1}\right)\end{array}$} & \multirow[b]{2}{*}{$\begin{array}{c}\text { Spray } \\
\text { Quality[a] }\end{array}$} & \multicolumn{3}{|c|}{ Droplet Spectrum } \\
\hline Sprayer & Nozzle & & & & & $\begin{array}{l}\mathrm{D}_{\mathrm{V} .10} \\
(\mu \mathrm{m})\end{array}$ & $\begin{array}{l}\mathrm{D}_{\mathrm{V} .50} \\
(\mu \mathrm{m})\end{array}$ & $\begin{array}{l}D_{\text {V.90 }} \\
(\mu \mathrm{m})\end{array}$ \\
\hline Boom sprayer & XR8004 & 234 & 1.32 & 145 & Medium & 115 & 275 & 480 \\
\hline Boom sprayer & XR8004 & 406 & 1.78 & 187 & Medium & 105 & 217 & 428 \\
\hline Boom Sprayer & TTJ60-11003 & 393 & 1.32 & 145 & Coarse & 179 & 300 & 523 \\
\hline Jacto air-assist sprayer & 11002AXI & 331 & 0.91 & 93 & Fine & 77 & 142 & 295 \\
\hline Jacto air-assist sprayer & 11002AXI & 813 & 1.32 & 145 & Fine & 68 & 136 & 283 \\
\hline Jacto air-assist sprayer & Jacto JA3 & 1040 & 1.32 & 145 & Fine & 59 & 116 & 186 \\
\hline
\end{tabular}

[a] As define by ASABE Standard S572 (ASABE Standards, 2004). 
critical droplet size above which larger droplets would be further broken up by parallel airflow would be over $4000 \mu \mathrm{m}$. It was not expected that the Jacto nozzle treatments would produce any significant number of droplets of this size.

In 2005, the broad-spectrum fungicide Headline (BASF, Florham Park, N.J.) was mixed to be applied at a rate of $420 \mathrm{~g}$ $\mathrm{ha}^{-1}$. In addition to allowing us to quantify the active ingredient (pyraclostrobin), this fungicide could also be used for efficacy evaluations if ASR were present. The concentration of pyraclostrobin in Headline was $23.6 \%$. No additional adjuvants were added to the spray mix. The 2006 tank mix included the insecticide Asana XL (DuPont, Wilmington, Del.) at $420 \mathrm{~g} \mathrm{ha}^{-1}$ for management of soybean aphids as well as the fungicide Headline mixed at $420 \mathrm{~g} \mathrm{ha}^{-1}$ for potential control of ASR. The Asana XL contained $8.4 \%$ by weight of the active ingredient esfenvalerate. The 2006 tank mix was prepared for a $145 \mathrm{~L} \mathrm{ha}^{-1}$ application. The same tank mix was used to make the higher $\left(187 \mathrm{~L} \mathrm{ha}^{-1}\right)$ and lower (93 $\left.\mathrm{L} \mathrm{ha}^{-1}\right)$ volumes.

All 2005 treatments were applied and allowed to dry for at least $10 \mathrm{~min}$ prior to sampling. All workers walking through treated plots wore protective clothing as prescribed by label instructions for early reentry into treated fields. In 2005, 20 plants were randomly chosen for sampling from each treated plot by workers. As a worker selected individual plants, the stem was cut at ground level and then the cut plant was handed to a second worker standing outside the treated plot. The second worker collected all sample plants before transferring them to the cutting station. Following measurement of plant height, approximately $25 \mathrm{~cm}$ of the top and $10 \mathrm{~cm}$ of the bottom of each plant were discarded depending on the height of the plant. The remaining portion of the plant was cut into two sections, one representing the bottom third of the plant by height and the other representing the middle of the canopy ranging to within $25 \mathrm{~cm}$ of the top of the plant. Leaves and stems were separated from each section and placed in separate paper bags for processing later. These bags were stored in a $-40^{\circ} \mathrm{C}$ freezer prior to processing. Plant sampling and removal in 2006 was similar to 2005 except that only ten plants were removed for sampling, the heights of two of the plants were measured, and all plants were sampled $24 \mathrm{~h}$ after treatment because of the label restrictions on reentry into an area treated with Asana XL.

Stem and leaf samples were ground in a stainless steel blender with dry ice and placed in a $-40^{\circ} \mathrm{C}$ freezer to minimize loss of pesticide before the extraction procedure. A dispersive solid-phase extraction technique was used to determine the amount of the active ingredient in Headline (pyraclostrobin) in soybean leaf and stem tissue (Anastassiades et al., 2003). A liquid chromatograph dual mass spectrometer (LC-MS/MS) system consisting of a ProStar 210 solvent delivery module with a ProStar 430 autosampler and a $1200 \mathrm{~L}$ triple-stage quadrupole mass spectrometer with a dual off-axis ESI interface (Varian, Inc., Walnut Creek, Cal.) was used to quantify the active ingredient in processed samples. The analyte was separated using a Polaris C18-A analytical column $(50 \times 2 \mathrm{~mm}$ ID, $5 \mu \mathrm{m})$ (Varian, Inc., Walnut Creek, Cal.). Mobile phase A was $0.1 \%(\mathrm{v} / \mathrm{v})$ formic acid $(\mathrm{pH}=2.7)$ and phase $\mathrm{B}$ was $0.1 \%$ formic acid $(\mathrm{v} / \mathrm{v})$ in acetonitrile, with a total flow rate of $0.2 \mathrm{~mL} \mathrm{~min}^{-1}$. The gradient started with $20 \% \mathrm{~B}$, held for $2 \mathrm{~min}$, increased to $90 \%$ in $2 \mathrm{~min}$, ramped to $100 \%$ in $1 \mathrm{~min}$, held for $1 \mathrm{~min}$, then returned to the initial condition in $1 \mathrm{~min}$, and was held for 2 min for equilibration of column and pumps. Transition ions 163, 194, and 296 were monitored for the molecular mass to charge ratio of 388 in positive ion mode.

The 2006 tissue samples were processed in a similar manner as the 2005 samples, but additional samples were processed separately to extract the active ingredient in Asana XL (esfenvalerate) by techniques adapted from Lee (2003). Gas chromatographic analysis of esfenvalerate was performed on a Varian 3800 GC coupled with a Varian 2200 ion trap mass spectrometer (Varian Inc., Walnut Creek, Cal.). Chemical ionization was used with acetonitrile as the liquid reagent. A $30 \mathrm{~m}$ Varian Factor Four 5MS column with an internal diameter of $0.25 \mathrm{~mm}$ and a film thickness of $0.25 \mu \mathrm{m}$ was used. The temperature program for the GC column consisted of a 2 min hold at $140^{\circ} \mathrm{C}$, then ramp to $270^{\circ} \mathrm{C}$ at $50^{\circ} \mathrm{C} \mathrm{min}-1$, holding for $10 \mathrm{~min}$. A splitless injection was made of each sample using the 1079 injector at a temperature of $240^{\circ} \mathrm{C}$ with the split off. Gas flow was at $1.0 \mathrm{~mL} \mathrm{~min}{ }^{-1}$. Quantification was performed by using a standard curve and by monitoring the 197 ion.

The hazards associated with handling of plant material treated with active ingredients required some additional care in the field and laboratory compared to dye tracers. Analysis of active ingredients was approximately five times more expensive per sample than evaluation of dyes on artificial targets.

The field experiment was run as a randomized complete block design (RCD), but it was not possible to get these analyses to converge correctly modeling for the replications as blocks. Chemical deposits on leaves and stems were analyzed using Friedman's test (Conover, 1980). The percentile within each replication was calculated to overcome problems of ranking data in cases of missing data within treatments. Separations of means tests were run following Conover (1980).

\section{RESUlts AND DisCuSSION}

No efficacy evaluations were possible in 2005 or 2006 because Asian soybean rust and soybean aphids were not detected in the test plots at the time of application.

Figure 1 shows the mean concentration of fungicide residue measured on leaf tissue in the 2005 field trials. Significant differences between treatments were detected for leaf tissue from the middle $(\mathrm{p}<0.0001)$ and lower $(\mathrm{p}=$ $0.0004)$ canopy sections. All treatments deposited more material on leaves sampled from the middle canopy area than the bottom of the canopy. Significantly higher residues were found on leaf tissue from the middle canopy area of the plots treated with the mechanical canopy opener using XR8004 nozzles than all other treatments. Among the flat-fan nozzles used to evaluate the effect of spray quality on penetration, the medium-quality XR8004 nozzle produced higher residue levels on leaf tissue from the middle canopy section, but not significantly greater than that found on samples treated by the fine-quality XR8002 and coarse-quality XR8005 nozzles.

The twin-fan spray pattern Turbo Duo and TX-18 hollowcone nozzles deposited less material on leaves in the middle of the canopy than the other treatments using flat-fan spray patterns. The Turbo Duo spray pattern was relatively shallow $\left(90^{\circ}\right)$ compared to the TwinJet treatment $\left(60^{\circ}\right)$, making it 


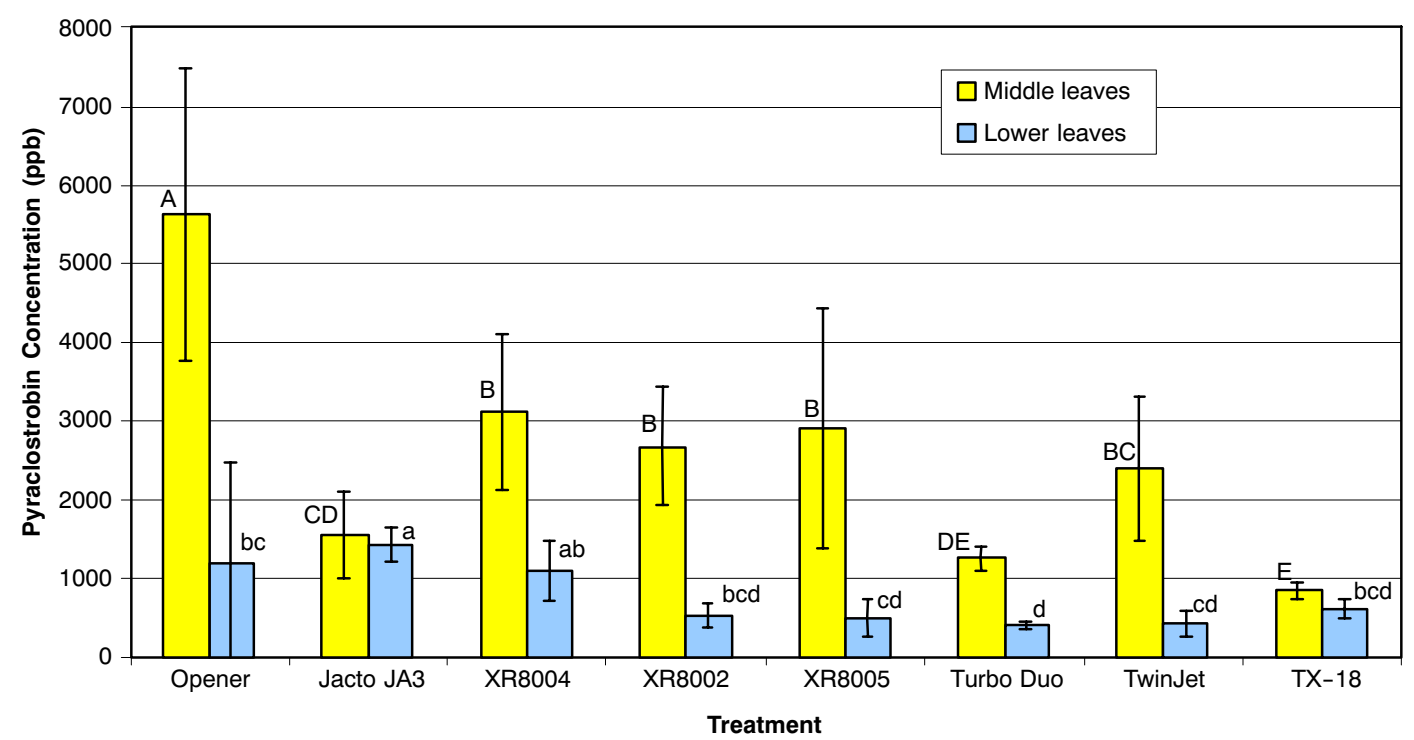

Figure 1. 2005 mean fungicide retention on leaf tissue across treatments. Uppercase letters represent significant difference $(p<0.05)$ among spray residue found at the middle canopy position. Lowercase letters represent significant difference $(p<0.05)$ among spray residue found on the lower canopy position. Error bars represent standard deviations of means.

appear that it might have more difficulty penetrating the dense canopy. The TX-18 hollow-cone nozzle produces relatively small and slow-moving droplets $\left(3.0 \mathrm{~m} \mathrm{~s}^{-1}\right)$, which may have contributed to its difficulty in penetrating the canopy. The Jacto air-assist sprayer with JA3 nozzles was not as effective at treating leaves in the middle of the canopy compared to any of the boom sprayer flat-fan treatments. However, the Jacto JA3 nozzle treatment was more effective at treating leaves in the lower canopy section compared to the other treatments (medium-quality XR8004 fan nozzle was statistically equivalent). Despite the mechanical opener producing slightly higher mean deposits on leaves in the lower canopy, because of a large amount of variability across all four replicates, statistically it did not treat the leaves in the lower canopy section as well as the Jacto JA3 treatment. Overall differences in amount of spray residue found on leaves in the lower canopy were smaller between treatments than that found in the middle canopy section.

A summary of the 2005 stem fungicide residue analysis is shown in figure 2 . Significant differences between treatments were detected for stem tissue from the middle $(p<0.0001)$ and lower $(p=0.0004)$ canopy sections. Residue levels detected on the stem tissue were significantly lower than that found on the leaf tissue (fig. 1) from the same canopy region. Stem tissue data for the middle section of the canopy were not available for the XR8002 nozzle. Significantly higher fungicide residue was found on stems from the middle canopy region treated by the mechanical opener with XR8004 nozzles except for the Jacto JA3 treatment. The medium-quality XR8004 nozzle deposited higher amounts of spray on stems in the middle of the canopy than the coarsequality XR8005 treatment. As observed on the leaf tissue, the

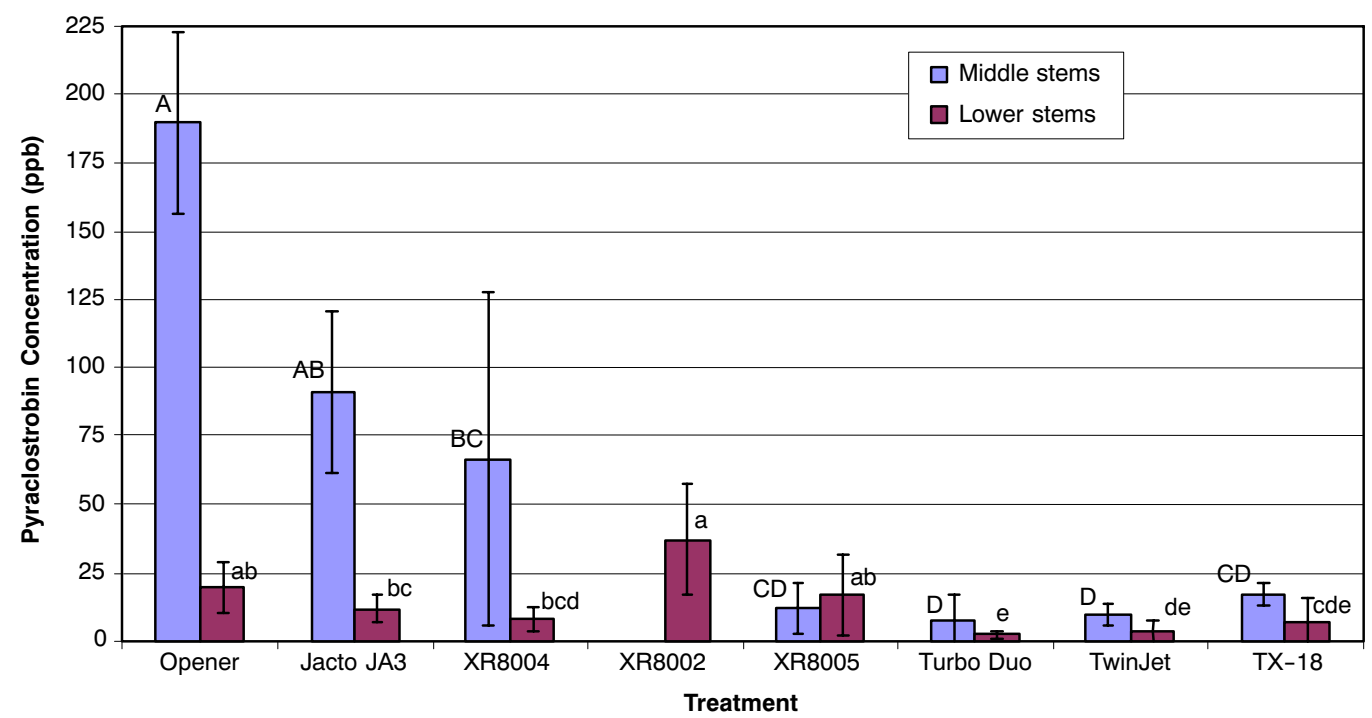

Figure 2. 2005 mean fungicide retention on stem tissue across treatments. Uppercase letters represent significant difference $(p<0.05)$ among spray residue found in the middle canopy position. Lowercase letters represent significant difference $(p<0.05)$ among spray residue found in the lower canopy position. Error bars represent standard deviations of means. 


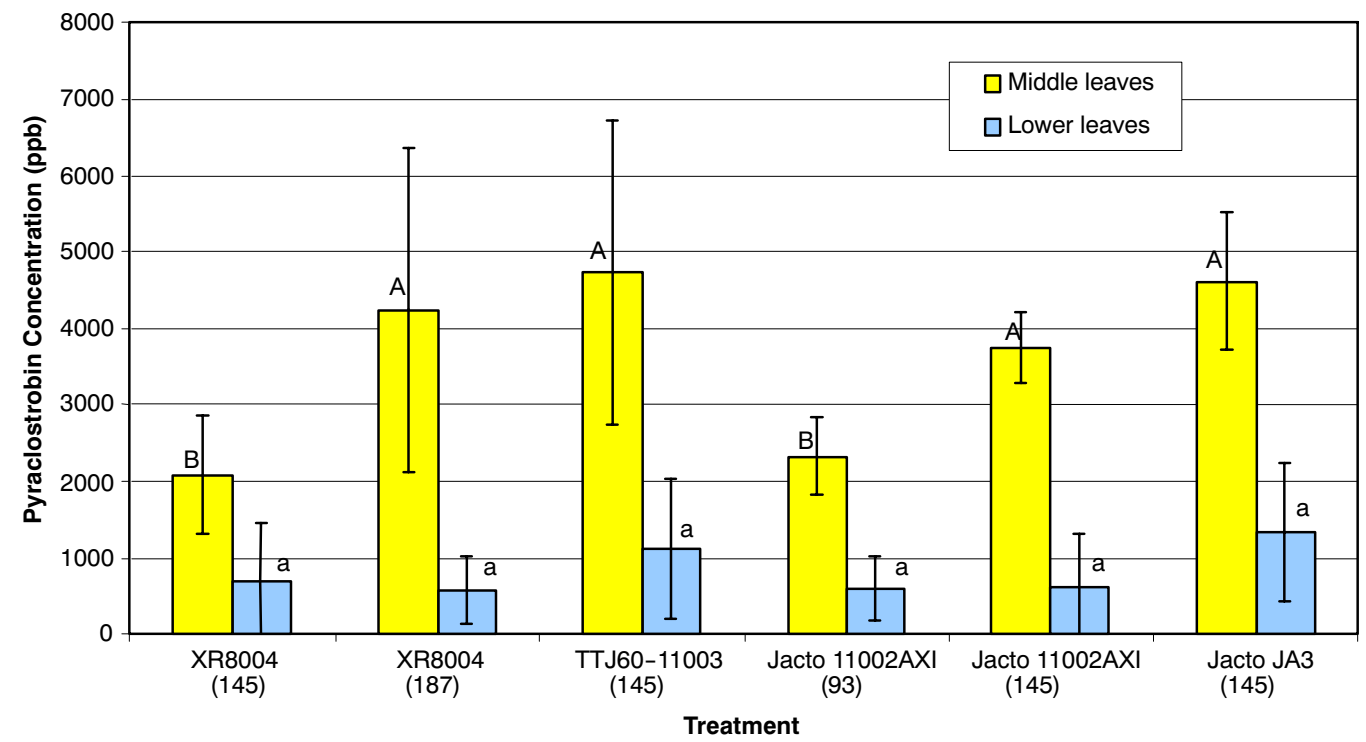

Figure 3. 2006 mean fungicide retention on leaf tissue across treatments. Uppercase letters represent significant difference (p < 0.05 ) among spray residue found at the middle canopy position. Lowercase letters represent significant difference $(\mathbf{p}<0.05)$ among spray residue found on the lower canopy position. Error bars represent standard deviations of means.

Turbo Duo and TX-18 nozzles were not effective at treating stems in either the middle or lower canopy sections compared to the other treatments, as was observed in the leaf tissue data. However, the Jacto JA3 treatments did not produce significantly higher amounts of residue on stems from the lower canopy section than the mechanical opener treatment or the flat-fan treatments. Significantly higher amounts of residue were found on stems from the lower canopy treated by the fine-quality XR8002 nozzle than all other treatments except the mechanical opener and XR8005 treatments.

Leaf tissue fungicide data for 2006 are shown in figure 3. Spray volume was a significant factor in the amount of fungicide residue detected on leaves taken from the middle canopy section. For the XR8004 and the Jacto 11002AXI treatments, higher spray volume resulted in significantly higher fungicide deposits. Since the same spray mix was used to make the $187 \mathrm{~L} \mathrm{ha}^{-1}$ application with the XR8004 nozzle as the $145 \mathrm{~L} \mathrm{ha}^{-1}$ application, it seems reasonable that higher amounts of fungicide were found on leaf tissue taken from the middle canopy. The difference in the amount of fungicide detected on the middle canopy leaves between the 145 and $187 \mathrm{~L} \mathrm{ha}^{-1}$ treatments is not entirely explained by the extra amount of fungicide being applied at the higher application volume and may be related to the higher operating pressure for the $187 \mathrm{~L} \mathrm{ha}^{-1}$ treatment. The difference between the 93 and $145 \mathrm{~L} \mathrm{ha}^{-1}$ Jacto $11002 \mathrm{AXI}$ treatments appears to be approximately the same as the difference in the amount of fungicide applied for each treatment. However, spray volume was not a factor in the amount of spray material detected on leaves taken from the lower canopy section, since the lower volume treatments performed similar to the higher volume treatments.

Nozzle type on the Jacto air-assist sprayer (flat-fan and hollow-cone) did not significantly affect the amount of fungicide residue found on leaves in the middle or lower canopy sections when applications were made at the same spray volume. There were no differences in the amount of fungicide residue found on leaves treated by the Turbo TeeJet TTJ60-11003 treatment and the higher volume XR8004 treatment. In addition, there were no differences in the amount of fungicide found on leaves treated with the TTJ60-11003 treatment and the air-assisted delivery treatments made at the same application volume. The TTJ60-11003 treatment may have been more effective at penetrating the 2006 soybean canopy than the Turbo Duo treatment was able to penetrate the 2005 canopy because the spray patterns were directed more vertically into the canopy. The angle between spray patterns for the TTJ60-11003 and Turbo Duo treatments were $60^{\circ}$ and $90^{\circ}$, respectively. There were no differences in the amount of fungicide residue found on leaves taken from the lower canopy between any of the 2006 treatments.

A summary of the analysis of fungicide residue on stem tissue treated in 2006 is presented in figure 4. Lower amounts of fungicide were found on stem tissue in 2006 compared to 2005. Reasons for the differences have not been explored, but it is possible that differences in canopy density played a role in the capture efficiency of the stem tissue. Similar to 2005, the highest amounts of fungicide residue were found on the stem tissue treated by the 2006 Jacto air-assist treatments (11002AXI and JA3). Spray volume was not a significant factor in the amount of fungicide found on lower canopy stem tissue in 2006. The mean amount of fungicide found on stem tissue treated by the Jacto JA3 treatment was higher than all other treatments, but Freidman analysis (Conover, 1980) took into account that the result for one replicate of the Jacto JA3 treatment was significantly higher than results for the other three replicates, thus reducing the overall effect of the outlier replicate.

Figure 5 shows the mean concentration of insecticide residue measured on leaf tissue in the 2006 field trials. Differences between treatments were detected at both canopy locations. Trends in the mean amount of insecticide found on leaf tissue were similar to the results of the fungicide analysis. Spray volume again affected the amount of pesticide residue found on leaves taken from the middle canopy. Higher volume resulted in higher amounts of residue. Considering, however, that the higher volumes also applied 


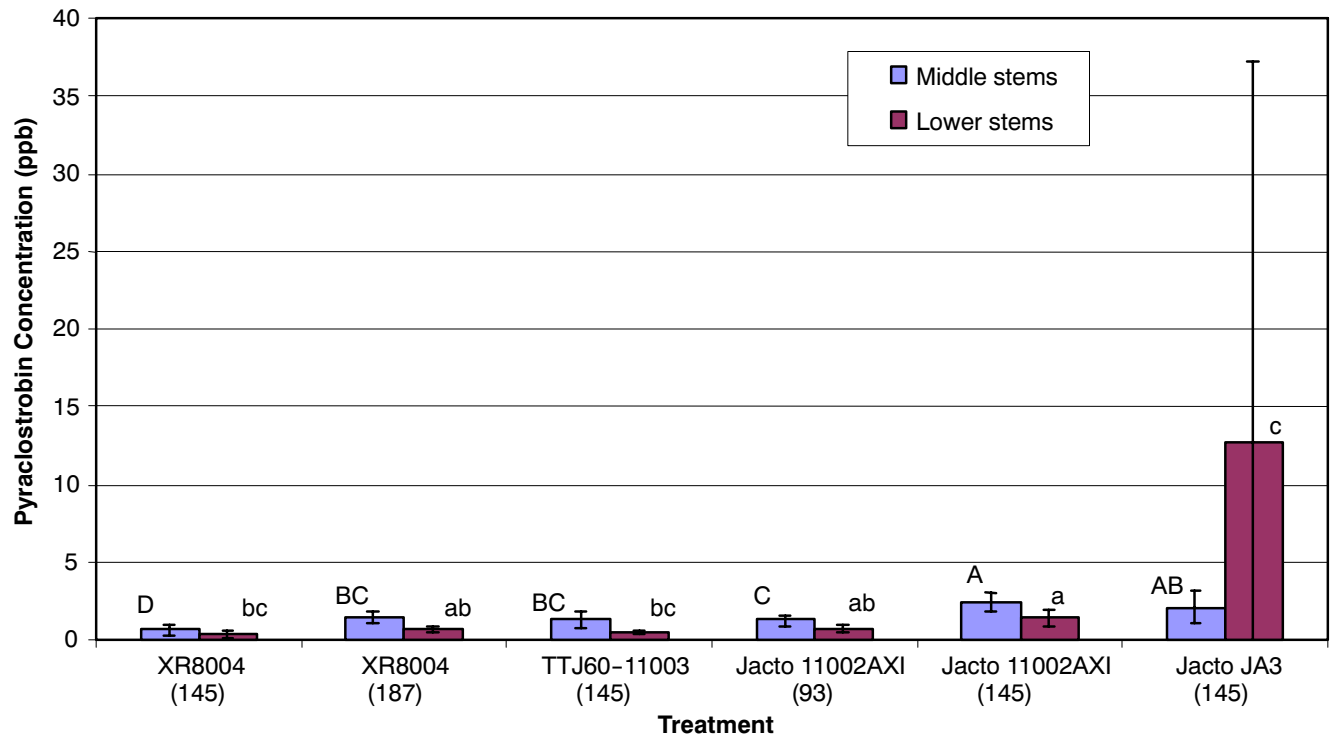

Figure 4. 2006 mean fungicide retention on stem tissue across treatments. Uppercase letters represent significant difference (p < 0.05) among spray residue found in the middle canopy position. Lowercase letters represent significant difference $(p<0.05)$ among spray residue found in the lower canopy position. Error bars represent standard deviations of means.

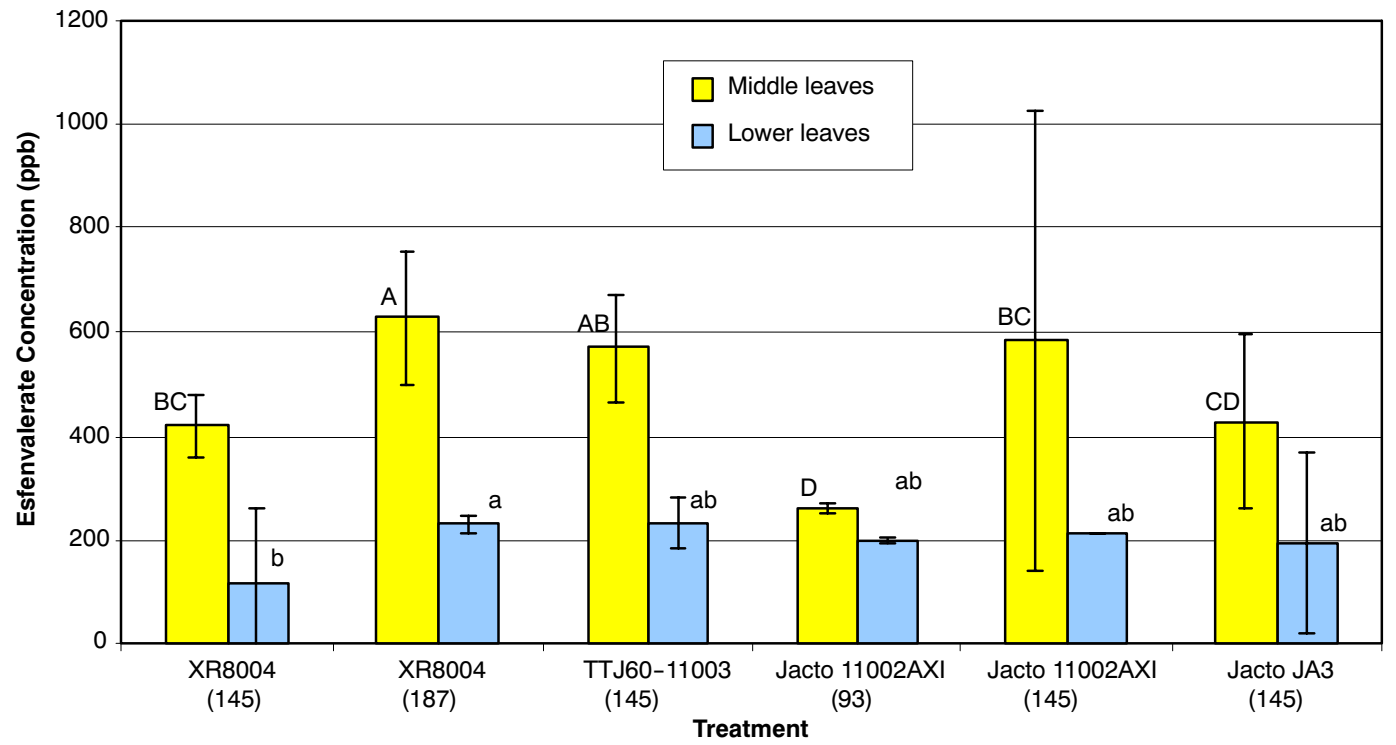

Figure 5. 2006 mean insecticide retention on leaf tissue across treatments. Uppercase letters represent significant difference $(\mathbf{p}<0.05)$ among spray residue found at the middle canopy position. Lowercase letters represent significant difference $(p<0.05)$ among spray residue found on the lower canopy position. Error bars represent standard deviations of means.

more active ingredient, the results appear to suggest that the lower volume treatments would not perform differently if the same concentration of pesticide had been applied for each treatment. Again, the Turbo TeeJet TTJ60-11003 treatment at $145 \mathrm{~L} \mathrm{ha}^{-1}$ deposited as much insecticide on leaves from the middle canopy as the higher volume XR8004 treatment and the Jacto 11002AXI treatment. Significantly higher concentrations of insecticide were found on leaf tissue treated by the TTJ60-11003 treatment than the Jacto JA3 treatment. All treatments resulted similar amounts of insecticide on leaves taken from the lower canopy except the lower volume XR8004 treatment.

A summary of the 2006 stem insecticide residue analysis is shown in figure 6. Within the detection limits of the analytical instruments used for the insecticide analysis and the methods used to extract the insecticide from the stem tissue, there was no insecticide detected on stem tissue taken from the lower canopy area. Compared to the fungicide analysis, the differences between the amount of insecticide found on the stem and leaf tissue in the middle canopy section were smaller due to lower amounts found overall and less active ingredient applied. The $145 \mathrm{~L} \mathrm{ha}^{-1}$ application XR8004 treatment produced higher amounts of insecticide residue on stem tissue from the middle of the canopy than all other treatments except for the Jacto 11002AXI treatment.

The XR8004 and Jacto JA3 treatments applying fungicide at $145 \mathrm{~L} \mathrm{ha}^{-1}$ were used in 2005 and 2006. Figure 7 summarizes the results across years for each treatment across all tissue samples. As shown in table 1, the 2006 canopy was shorter and less dense than the 2005 canopy. Each sprayer 


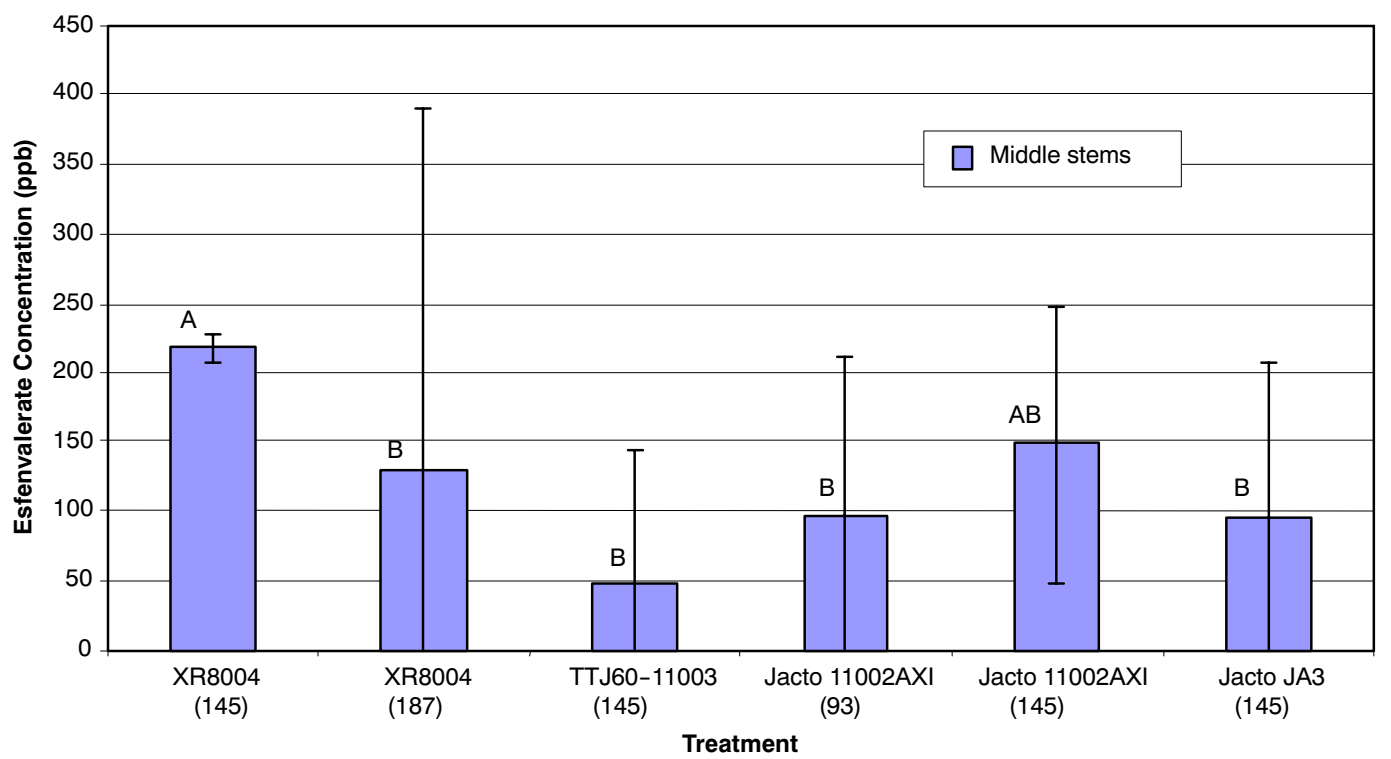

Figure 6. 2006 mean insecticide retention on stem tissue across treatments. Letters represent significant difference $(p<0.05)$ among spray residue found in the middle canopy position. Error bars represent standard deviations of means.

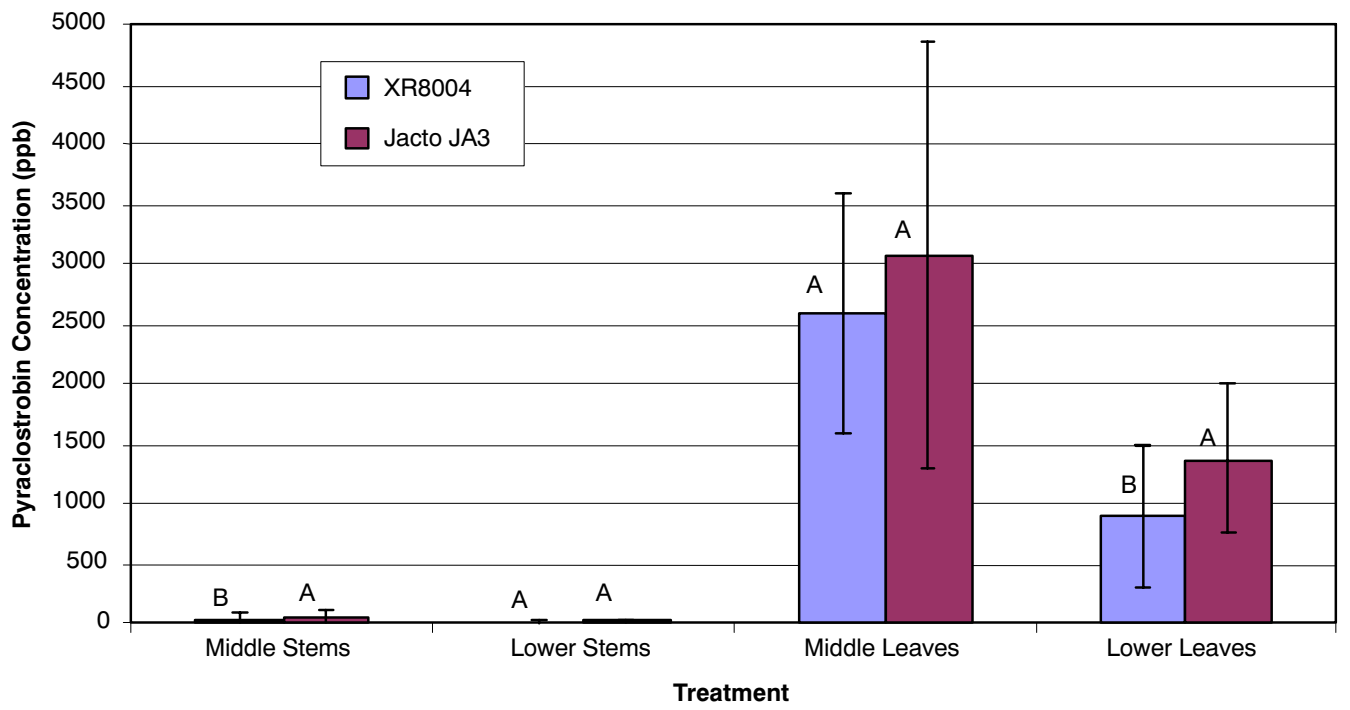

Figure 7. Combined 2005 and 2006 mean fungicide retention on stem and leaf tissue across XR8004 and Jacto JA3 treatments. Letters represent significant difference $(p<0.05)$ among spray residue found in between each pair of treatments. Error bars represent standard deviations of means.

performed somewhat differently each year. Overall, the Jacto JA3 treatment resulted in higher amounts of fungicide residue on leaves taken from the lower canopy and stem tissue from the middle canopy. There were no differences between these treatments across years in the amount of fungicide residue found on leaf tissue from the middle canopy or stem tissue from the lower canopy.

\section{SumMARY AND CONCLUSIONS}

While more time consuming and costly than using artificial tracers, these studies with active ingredients help to better understand the fate of spray on stems and leaves in narrow-row $(18 \mathrm{~cm})$ soybean canopies. Lack of soybean aphids and ASR at the field sites eliminated the possibility of any biological efficacy in these studies. Spray coverage was not correlated with the amount of spray residue quantified in this article.
Much lower concentrations of pesticide residue were found on stem tissue than leaf tissue. This could have been a result of differences in capture efficiency of more cylindrical and more vertical surfaces of the stem structures or some other differences in physical characteristics between stems and leaves that was not evaluated here.

Differences in application methods were identified. In individual years of study, the air-assist treatment did not necessarily perform better in the soybean canopies than all other treatments; across both years, there was some indication that the air-assisted delivery was superior to a conventional flat-fan nozzle treatment at $145 \mathrm{~L} \mathrm{ha}{ }^{-1}$. However, these results did not evaluate the quality of spray deposit on leaf or stem tissue, and they did not attempt to quantify differences in the amount of pesticide residue on upperside and underside leaf surface. Given that many other research reports have demonstrated that air-assisted delivery, when matched with the proper droplet size spectrum, can 
improve underside leaf spray coverage, it is likely that airassistance could also help provide effective soybean pest management.

The fungicide residue analysis in this study indicated that for the range of spray volumes and treatments evaluated, spray volume does not necessarily impact the amount of pesticide residue found on plant tissue throughout a canopy if the pesticide is applied at the same rate. It would be expected, however, that higher spray volumes would increase spray coverage, which could impact efficacy.

Spray quality was not a good predictor of the amount of residue measured on plant tissue. Medium-quality sprays performed somewhat better than fine-quality and coarsequality flat-fan nozzles at the same spray volume. The largedroplet TTJ60-11003 twin-fan spray nozzle, however, produced higher amounts of pesticide residue than the singlefan, flat-fan nozzles for $145 \mathrm{~L} \mathrm{ha}^{-1}$ applications. In addition, a small-droplet nozzle such as the TX-18 hollow-cone nozzle that produces slower-moving droplets on average than flatfan nozzles resulted in significantly lower deposits on leaves than flat-fan treatments. Based on these results, fine-quality sprays should be avoided for treating lower portions of a soybean canopy unless some other form of energy, such as air-assistance, is provided to help move droplets deeper into a canopy.

These results also demonstrate that it would be inappropriate to characterize nozzle performance by spray pattern alone. In these studies, one style twin-fan nozzle resulted in higher pesticide residues than other twin-fan nozzle designs and a hollow-cone spray pattern nozzle design. Spray angle, droplet size, and droplet velocity may be more important factors for determining soybean canopy penetration than spray pattern.

\section{ACKNOWLEDGEMENTS}

The help provided by Dr. Huseyin Güler and Dennis Mills of the Ohio State University and staff at the USDA-ARS Application Technology Research Unit is much appreciated. The authors recognize and appreciate the assistance of Leslie Morris for conducting and coordinating the analytical evaluations of the soybean samples in Wooster and at the University of Toledo with the cooperation of Jason Witter. The authors are also grateful for the help provided by Bert Bishop and Leona Horst with the statistical analysis of these results.

The authors thank the OSU/OARDC and ATI farm operations for providing the soybean fields where these studies were conducted. The authors also acknowledge financial support for this research from Ohio Soybean Council, BASF Corporation, Corn and Soybean Digest, Gregson Technologies, Jacto Inc., Spraying Systems Co., and Unverferth Equipment Co.

\section{REFERENCES}

Anastassiades, M., S. J. Lehotay, D. Stajnbaher, and F. J. Schenck. 2003. Fast and easy multiresidue method employing acetonitrile extraction/partitioning and "dispersive solid-phase extraction" for determination of pesticide residues in produce. J. AOAC Intl. 86(2): 412-431.

ASABE Standards. 2004. S572: Spray nozzle classification by droplet spectra. St. Joseph, Mich.: ASABE.

Conover, W. J. 1980. Practical Nonparametric Statistics. 2nd ed. New York, N.Y.: John Wiley and Sons.

Cunha, J. P. A. R., E. F. Reis, and R. O. Santos. 2006. Controle químico da ferrugem asiática da soja em função de ponta de pulverização e de volume de calda. Ciencia Rural 36(5): 1360-1366.

Derksen, R. C., S. A. Miller, H. E. Ozkan, and R. D. Fox. 2001. Spray deposition characteristics on tomatoes and disease management as influenced by droplet size, spray volume, and air-assistance. ASAE Paper No. 011120. St. Joseph, Mich.: ASAE.

Derksen, R. C., S. Vitanza, C. Welty, S. Miller, M. Bennett, and H. Zhu. 2007. Field evaluation of application variables and plant density for bell pepper pest management. Trans. ASABE 50(6): 1945-1953.

Fox, R. D., R. D. Brazee, D. L. Reichard, and F. R. Hall. 1982. Power in an air sprayer jet. Trans. ASAE 25(5): 1181-1184, 1188.

Lefebvre, A. H. 1989. Atomization and Sprays. New York, N.Y.: Hemisphere Publishing.

Lee, P. W., ed. 2003. Handbook of Residue Analytical Methods for Agrochemicals. Vol. 2. New York, N.Y.: John Wiley and Sons.

Mueller, D. S., A. E. Dorrance, R. C. Derksen, E. Ozkan, J. E. Kurle, C. R. Grau, J. M. Gaska, G. L. Hartman, C. A. Bradley, and W. L. Pedersen. 2002. Efficacy of fungicides on Sclerotinia sclerotiorum and their potential for control of Sclerotinia stem rot soybean. Plant Dis. 86(1): 26-31.

Mullins, C. A., F. D. Tompkins, and D. J. Canary. 1981. The effect of sprayer pressure, water volume, and nozzle configuration on snap bean rust control with Bravo. Bean Improvement Cooperative Annual Report 24: 58.

Piché, M., B. Panneton, and R. Thériault. 2000. Field evaluation of air-assisted boom spraying on broccoli and potato. Trans. ASAE 43(4): 793-799.

Reichard, D. L., R. D. Fox, and R. D. Brazee. 1979. Air velocities delivered by orchard air sprayers. Trans. ASAE 22(1): 69-74, 80.

Ruden, B. E., M. A. Draper, and K. R. Ruden. 2006. 2006 Soybean fungicide sprayer trials. Annual Progress Report No. 46. Beresford, S.D.: Southeast South Dakota Experiment Farm.

Wolf, R. E., and N. P. Daggupati. 2006. Nozzle type effect on soybean canopy penetration. ASABE Paper No. 061163. St. Joseph, Mich.: ASABE.

Womac, A. R., J. E. Mulrooney, and W. P. Scott. 1992. Characteristics of air-assisted and drop-nozzle sprays in cotton. Trans. ASAE 35(5): 1369-1376.

Zhu, H., D. L. Rowland, J. W. Dorner, R. C. Derksen, and R. B. Sorensen. 2002. Influence of plant structure, orifice size, and nozzle inclination on spray penetration into peanut canopy. Trans. ASAE 45(5): 1285-1301.

Zhu, H., J. W. Dorner, D. L. Rowland, R. C. Derksen, and H. E. Ozkan. 2004. Spray penetration into peanut canopies with hydraulic nozzle tips. Biosystems Eng. 87(3): 275-283.

Zhu, H., R. C. Derksen, H. E. Ozkan, H. Güler, R. D. Brazee, M. Reding, and C. R. Krause. 2006. Development of a canopy opener to increase spray deposition and coverage inside soybean canopies. ASABE Paper No. 061164. St. Joseph, Mich.: ASABE. 
